\title{
KONSTRUKSI KAUSATIF ANALITIK DALAM BAHASA JAWA DAN BAHASA INDONESIA
}

\author{
Tuti Nurhayati \\ Surel: tutynurhayati28@gmail.com
}

\begin{abstract}
This study aims to reveal how the Javanese and Indonesia language is formed in the perspective of analytic causative construction. The analytic causative concept refers to the causative concept according to Comrie (1989). This research data is obtained from written sources. The markup method is applied in analyzing research data based on the issues discussed in this article. The results of this study indicate that the analytic causative construction in Javanese can be formed with the verb nggawe (make). Javanese analytic construction has a biclausal structure, as seen from their ability to take polarity and different modalities for verbs. While in causative analytic language can be formed with various verbs such as: make, cause, invite, enjoin, ask and make and have monoklausa structure.
\end{abstract}

Keywords: Analytic causative, Javanese, Indonesian, method of marking

\begin{abstract}
ABSTRAK
Penelitian ini bertujuan untuk mengungkap bagaimana bahasa Jawa dan bahasa Indonesia terbentuk dalam sudut pandang kontruksi kausatif analitik. Konsep kausatif analitik tersebut mengacu kepada konsep kausatif menurut Comrie (1989), Data penelitian ini di peroleh dari sumber tertulis. Metode markah diterapkan dalam menganalisis data penelitian berdasarkan permasalahan yang dibahas dalam artikel ini. Hasil penelitian ini menunjukkan bahwa konstruksi kausatif analitik dalam bahasa Jawa dapat dibentuk dengan verba nggawe (membuat). Konstruksi analitik jawa memiliki struktur biclausal, seperti yang terlihat dari kemampuan mereka untuk mengambil polaritas dan modalitas yang berbeda untuk kata kerja. Sedangkan dalam bahasa Indonesia kausatif analitik dapat dibentuk dengan verba yang beragam seperti: membuat, menyebabkan, mempersilahkan, menyuruh, meminta dan membikin serta memiliki struktur monoklausa.
\end{abstract}

Kata Kunci: Kausatif analitik, Jawa, Indonesia, metode markah

\section{PENDAHULUAN}

Konstruksi kausatif merupakan bentuk konstruksi yang selalu ada dalam konstruksi tipologi setiap bahasa. Setidaknya ada tiga cara untuk mengekspresikan kausativisasi, yaitu: kausatif analitik, kausatif morfologi, dan kausatif leksikal (Comrie, 1981). Kausatif analitik adalah kausatif yang memiliki predikat atau kata kerja terpisah untuk mengungkapkan penyebab dan penyebabnya. Kausatif morfologi terjadi bila hubungan antara predikat non-kausatif dan kausatif ditandai dengan cara morfologi atau afiks, dan kausatif leksikal adalah di mana hubungan antara kejadian yang disebabkan dan menyebabkan tidak ada hubungannya dengan tanda baku (morfologi), seperti pada kata kerja bahasa Indonesia membunuh "membunuh", dan kata kerja mbukak "terbuka" pada bahasa Jawa. Ditinjau dari parameter formal (Comrie, 
1989), pada dasarnya ada dua jenis kausatif: kausatif perifrastik/analitik dan kausatif morfologi/leksikal. Dalam kasus ini, tipe pertama mengacu pada konstruksi kausatif yang bersifat biklausal, sedangkan yang kedua bersifat monoklausal. Dengan kata lain, kausatif morfologi dan leksikal diperlakukan secara sintaktis dengan cara yang sama dalam arti monoklausal.

Tipe-tipe konstruksi kausatif yang dimiliki oleh setiap bahasa berbeda satu dengan yang lainnya. Ada bahasa yang memiliki ketiga tipe konstruksi (kausatif leksikal, kausatif morfologis dan kausatif analitik) dan ada juga bahasa yang hanya memiliki dua tipe konstruksi kausatif; kausatif leksikal dan kausatif analitik. Bahasa yang memiliki ketiga tipe konstruksi pada umumnya merupakan bahasa yang bertipe aglutinasi karena bahasa bertipe ini mempunyai afiks yang dapat dilekatkan pada verba yang berfungsi menaikkan atau menurunkan valensi verba. Sementara, bahasa yang hanya memiliki dua tipe kausatif merupakan bahasa yang bertipe isolasi karena bahasa tersebut pada umumnya tidak memiliki afiks yang berfungsi untuk menaikkan atau menurunkan valensi verba (Budiarta: 2015).

Kausatif analitik dan leksikal biasanya terjadi dalam mengisolasi bahasa, sedangkan kausatif morfologi umumnya terjadi pada bahasa polisintetik (lihat Bishop, 1992). Bahasa Inggris (Hollmann,
2003), Thai (Sudmuk, 2005), dan Rongga (Arka et.al, 2007) merupakan bahasa yang memiliki kausatif leksikal dan analitik namun tidak bersifat morfologi. Bahasabahasa ini tidak memiliki sarana morfologi atau afiks untuk mengekspresikan kausatif. Sebaliknya, beberapa bahasa seperti Kewa dan Papua Nugini (lihat Bishop, 1992) memiliki kausatif morfologis namun tidak memiliki kausatif analitik.

Bahasa Indonesia juga memiliki ungkapan yang digunakan untuk mengekspresikan makna kausatif seperti contoh berikut ini.

(1) Berita itu membuat hatinya gembira. (2) Perbuatannya menyebabkan orang-orang di dekatnya merasa gembira. (3) Ibu membersihkan kamar tidur. (4) Perampok itu juga membunuh korbannya.

Pada contoh di atas verba membuat, menyebabkan, membersihkan, dan membunuh merupakan verba yang menyatakan makna kausatif. Verba kausatif dalam bahasa Indonesia bentuknya dapat berupa verba berafiks maupun bukan verba berafiks. Contoh (1) dan (2) merupakan konstruksi kausatif analitik yang ditandai dengan verba membuat dan menyebabkan, sedangkan contoh (3) disebut kausatif morfologis karena adanya penambahan affiks pada kata membersihkan dan pada contoh (4) merupakan kausatif leksikal. Subjek kalimat (1-4) di atas yaitu Berita itu, Perbuatannya, Ibu, dan Perampok 
itu menjadi penyebab yang memberi pengaruh kepada objek dia, orangorang di dekatnya, kamar tidur, dan korbannya sehingga objek melakukan suatu tindakan atau mengalami suatu peristiwa. Dilihat dari maknanya, kausatif bahasa Indonesia mengekspresikan subjek menyebabkan objek menjadi mengalami sesuatu.

Dalam bahasa Indonesia konstruksi kausatif analitiknya dapat dibentuk dengan verba membuat, menyebabkan, mempersilahkan, menyuruh, meminta dan membikin. Konstruksi kausatif analitik dalam bahasa Indonesia sangat produktif, hal ini dikarenakan bahasa Indonesia merupakan gabungan dari beberapa bahasa-bahasa daerah, maka menarik untuk meneliti mengenai kesamaan dan perbedaan konstruksi kausatif bahasa Indonesia dan bahasa daerah di Indonesia., salah satunya bahasa Jawa.

Bahasa jawa merupakan salah satu bahasa daerah yang terdapat di pulau Jawa dengan jumlah penutur terbesar di Indonesia dan peringkat ke 11 di dunia dengan jumlah penutur 75.500.000. Dalam bahasa Jawa, kausatif analitiknya terdiri dari dua kata kerja untuk mengungkapkan penyebab dan penyebabnya yaitu nggawe dan marakake. Konstruksi penyebab dengan kata kerja nggawe berbeda dengan kata kerja marakake. Penggunaan kata kerja nggawe dalam konstruksi kausatif menyiratkan tindakan kehendak, sementara penggunaan kata kerja marakake tidak menunjukkan tindakan kehendak.

Orang Jawa memiliki penanda morfologi atau memiliki akhiran makna yang mirip. Selain itu, bahasa ini menggunakan verba terpisah yang mengungkapkan penyebab dan penyebabnya seperti pada kausatif analitik. Contoh berikut adalah konstruksi kausatif dalam bahasa Jawa.

(5) a. Rudi nggawe ibune seneng. Rudi membuat ibunya bahagia.

b. Rudi nyenengake ibune. Rudi menyenangkan ibunya.

Contoh (5-a) adalah suatu kausatif analitik, yang terdiri dari dua predikat: nggawe "membuat" dan seneng "bahagia", sedangkan contoh (5-b) adalah kausatif morfologis karena kalimat ini menggunakan penanda morfologi atau akhiran kausatif -ake untuk mengubah kata kerja non-kausatif menjadi kausatif. Perbedaan antara kausatif morfologi dan analitik berkaitan dengan faktor semantik, yang salah satunya menyangkut kausatif langsung atau tidak

langsung. Kausatif analitik menunjukkan kausatif tidak langsung, sedangkan kausatif morfologi menunjukkan sebab akibat langsung, di mana kausatif 'langsung' ditindaklanjuti oleh kausatif pada momen tertentu (lihat Arka, 1993; Comrie, 1989).

Berdasarkan pemaparan di atas, dalam penelitian ini akan dibahas,1) bentuk konstruksi kausatif analitik dalam bahasa Jawa. 
Kemudian, 2) persamaan dan perbedaan bentuk konstruksi kausatif analitik bahasa Jawa dan bahasa Indonesia. Hal ini di karenakan dalam konstruksi kausatif analitik, komponen sebab dan komponen akibat muncul secara eksplisit di dalam kalimat. Komponen sebab dan komponen akibat tersebut atau situasi-situasi mikro pada kausatif analitik lebih mudah diuraikan. Selain itu dikarenakan masih sedikitnya penelitian yang membahas bahasa Jawa terkhusus dalah hal perbandingan konstruksi kausatifnya dengan bahasa Indonesia.

\section{METODE PENELITIAN}

Metode yang digunakan dalam penelitian ini menggunakan teknik markah. Pemarkahan menunjukkan kejadian satuan lingual atau konstituen tertentu dan kemampuan membaca peranan pemarkah itu sendiri untuk menentukan kejadian yang dimaksud. Praktik penggunaanya sangat khas, tidak menggunakan alat sebagaimana teknik lainya melainkan melihat langsung pemarkah yang bersangkutan. Adapun untuk melihatnya, hal itu dapat dilakukan secara sintaksis. Di samping pemarkah yang corporal, ada pemarkah jenis lain yang tidak terkait secara khusus bentuk demi

bentuk tetapi melingkupi sekian banyak bentuk lingual yang berbeda-beda dengan maksud pragmatis yang sama seperti yang ada perualangan bervariasi bunyi. Dalam bahasa Jawa, perulangan bervariasi bunyi vokal menampakan wujud yang beraneka mulai dari bentuk dasar mlayu'lari', mangan'makan', walik'balik', terbentuklah perulangan dengan variasi vokal mloya-mlayu, monganmangan, wolak-walik (Sudaryanto, 2015: 129-133) dan dalam penelitian ini menggunakan kausatif analitik. Oleh karena itu penelitian ini menggunakan teknik pemarkah sebagai metode penelitian dan kontruksi kausatif analitik sebagai

dasar penentuan pemarkahnya. Selanjutnya penelitian ini meliputi pengumpulan data dan analisis data. Penelitian dimulai dengan proses menjaring data, mengumpulkan,

mengidentifikasi, dan mengklasifikasikanya. Selanjutnya, data yang sudah diklasifikasikan dianalisis dengan langkah-langkah yang sesuai. Untuk mengetahui penggunaan konstruksi kausatif tersebut dalam kalimat bahasa Jawa, diperlukan data yang mendukung analisis. Oleh karena itu, penelitian ini dimulai dengan pengumpulan data dan dilanjutkan dengan analisis data dengan tujuan yang ingin dicapai dalam penelitian ini.

\section{HASIL PENELITIAN DAN PEMBAHASAN}

Kausatif analitik terdiri dari dua predikat atau verba, yang berfungsi sebagai predikat1 dan predikat2. Sesuai dengan contoh di bawah, dalam bahasa Jawa, predikat1 diisi dengan kata kerja nggawe "membuat" atau ingkang

"menyebabkan", dan predikat2 
adalah keadaan, proses, maupun kata kerja yang melakukan suatu tindakan atau mengakibatkan kejadian. Kata kerja kausatif nggawe dan ingkang secara semantik berbeda dalam arti bahwa dengan kata kerja nggawe,

kejadian yang terjadi yang disebabkan oleh tindakan yang dikehendaki, sedangkan dengan verba ingkang, tindakan pada pihak penyebab tidak dikehendaki atau tidak di inginkan. Hal ini terjadi bila penyebabnya adalah manusia. Untuk membuktikannya, kata keterangan ingkang "menyebabkan" (7) bisa terjadi sebelum kata kerja nggawe pada contoh (6), bukan sebelum kata kerja ingkang seperti pada contoh (7).

(6) Ripin Nggawe gindhel melebu neng omah.

"Ripin membuat kelerengnya masuk ke dalam rumah".

(7) Budi ora ingkang dipunsengaja omah ndee kobongan.

"Budi tidak sengaja menyebabkan rumahnya kebakaran".

Penyebab analitik dalam bahasa Jawa biasanya memiliki urutan kata SVOV. Dengan kata lain, antara predikat1 dan predikat2 ada frase kata benda (KB) menjadi objek (OB) gramatikal dari kata kerja kausatif. Namun, ketika predikat2 diisi dengan kata kerja dengan maksud menyampaikan seperti kata kerja linglung "bingung", bungah "bahagia", ngelongsoh "sedih", maka predikat2 dapat langsung dipasangkan setelah predikat1, menghasilkan pola SVVO, yang merupakan variasi dari pola kanonik urutan kata SVOV. Contoh dibawah ini menunjukkan urutan kata dalam konstruksi kausatif bahasa Jawa.

(8) a. Pipin nggawe ndee penggalih wae.

"Pipin membuat dia kepikiran saja"

b. Pipin nggawe penggalihndee wae

"Pipin membuat kepikiran dia saja.

(9) a. Ndee iku nesu sing nggawe kui ngelosngso.

"Dia itu marah yang membuat kalian sedih".

b. Ndee iku nesu sing nggawe ngelosngsoh kui. "Dia itu marah yang membuat pergi kalian”.

Kalimat (9) menunjukkan
bahwa predikat 2 ngelongsoh
"sedih", yang merupakan kata kerja
yang menghasilkan tindakan, harus
terjadi setelah obyek seperti pada
kalimat (9-a), dan tidak dapat
dipasangkan langsung setelah predikat1, seperti pada (9-b). Ini berbeda dengan kalimat (8) yang memiliki dua kemungkinan perintah karena kalimat ini memiliki predikat2 penggalih "kepikiran" dengan kata kerja yang melakukan tindakan dan menghasilkan. Data kausatif analitik seperti yang disajikan di atas menimbulkan pertanyaan, yaitu apakah monoklausa atau biklausa. Untuk 
menjawab pertanyaan ini, model sintaksis seperti negasi dan modal dapat diterapkan. Dalam bahasa Jawa, negasi dan modal hanya terjadi sebelum kata kerja yang telah dirubah. Jika kita mengklaim bahwa kausatif analitik adalah monoklausa, predikat1 dan predikat2 harus mendapatkan polaritas dan modalitas yang sama, dan tidak diijinkan untuk predikat1 dan predikat2 untuk mendapatkan polaritas dan indikator modal yang berbeda. Penggunaan penanda negasi ora "tidak" dan modal bisa "dapat" dalam konstruksi kausatif analitik dapat dilihat pada (10) dan (11) di bawah ini.

(10) Mbokke ora nggawe ndee nesu "Ibunya tidak akan membuatnya marah".

(11) Mbokke nggawe ndee ora nesu "Ibunya mencegahnya untuk marah".

Kalimat di atas menunjukkan bahwa predikat1 dan predikat 2 bisa mendapatkan polaritas dan modalitas yang berbeda. Dalam (10), penanda negasi ora memodifikasi verba nggawe sehingga menghasilkan sesuatu yang diinginkan, sedangkan pada (11), negasi memodifikasi kata kerja nesu sehingga menghasilkan sesuatu yang di cegah. Hal ini menunjukkan bahwa predikatl dan predikat2 tidak membentuk satu predikat tunggal. Penggunaan modal bisa "dapat" yang dapat memodifikasi predikat1. Hal ini menunjukkan bahwa kausatif analitik bahasa Jawa bersifat biklausa.
Persamaan konstruksi kausatif analitik dalam bahasa Jawa dan bahasa Indonesia sama-sama memiliki dua predikat disetiap konstruksinya dan bersifat biklausa. Seperti penjelasan contoh dibawah ini.

(12) a. Dina menangis lagi.

b. Foto itu membuat Dina menangis lagi.

(13) a. Mahasiswa selalu mencari dosen.

b. Tugas makalah itu, membuat mahasiswa selalu mencari dosen.

\section{Pembahasan}

Berdasarkan contoh di atas dapat dilihat bahwa konstruksi kausatif pada (12-b) dan (13-b) terbentuk dari konstruksi nonkausatif (12-a) dan (13-a). Dilihat dari jenis predikatnya, predikat konstruksi nonkausatif (12-a) berupa verba intransitif, sedangkan konstruksi nonkausatif (13-a) berupa verba transitif. Dari contoh di atas dapat kita ketahui bahwa perubahan

konstruksi nonkausatif, baik konstruksi dengan predikat verba dasar intransitif (12-a) maupun dengan verba transitif (13-a), menjadi konstruksi kausatif (12-b) dan (13-b) yang mengharuskan kehadiran verba kausatif membuat. Kehadiran verba kausatif membuat ini menyebabkan konstruksi kausatif analitik tersebut memiliki dua predikat dalam setiap konstruksinya. Akibat dari penambahan verba kausatif membuat adalah adanya penambahan satu argument yang 
berfungsi sebagai penyebab. Kehadiran verba membuat pada kalimat (12-b) menuntut kehadiran Foto itu sebagai penyebab sehingga memunculkan akibat Dina menangis lagi. Demikian pula dengan kalimat (13-b), verba kausatif membuat

\begin{tabular}{lr} 
menyebabkan Tugas makalah & \multicolumn{1}{c}{ mesuatu } \\
(seolah-olah) melakukan & sesingga \\
terhadap mahasisawa & sehingga \\
mahasiswa selalu mencari dosen.
\end{tabular}

Sedangkan perbedaannya, konstruksi kausatif analitik dalam bahasa Jawa dapat dibentuk dengan verba nggawe, dalam bahasa Indonesia lebih beragam, seperti:

membuat, menyebabkan, mempersilahkan, menyuruh, meminta dan membikin. Perhatikan contoh dibawah ini:

(14) Kenaikan harga cabai yang sangat drastis, membuat para ibu-ibu resah.

(15) Dina tidak tahu apa yang menyebabkan dia dijauhi oleh teman- temannya.

(16) Heri mempersilahkan temantemannya untuk datang ke rumahnya.

(17) Ibu menyuruh kakak untuk membakar sampah dibelakang rumah.

(18) Riko meminta Bella untuk menerima cintanya.

(19) Hari ini ayah membikin hati ibu senang.

Contoh (14) menunjukkan bahwa komponen sebab ditandai oleh verba membuat yang secara eksplisit menjelaskan sebagai penyebab, yaitu Kenaikan harga cabai, seolah-olah melakukan sesuatu terhadap para ibu-ibu dan komponen akibat secara eksplisit ditandai oleh predikat resah pada para ibu-ibu resah. Jadi, pada konstruksi kausatif analitik ini makna bahwa penyebab (kenaikan harga cabai) melakukan sesuatu terhadap tersebab (para ibu-ibu) sehingga memunculkan akibat (para ibu-ibu resah) yang hadir secara eksplisit dalam struktur kalimat tersebut.

\section{SIMPULAN}

Pembentukan kausatif yang dibahas pada bagian ini meliputi kausatif analitik dalam bahasa Jawa serta persamaan dan perbedan konstruksi kausatif analitik pada bahasa Jawa dan bahasa Indonesia.

Pada pembentukan konstruksi kausatif analitik dalam bahasa Jawa dapat dibentuk dengan menggunakan kata kerja nggawe dan marakake. Kata kerja yang menyatakan penyebab bisa berupa keadaan atau kata kerja tindakan. Konstruksi kausatif dengan kata kerja nggawe berbeda dengan kata kerja marakake. Penggunaan kata kerja nggawe dalam konstruksi kausatif menyiratkan tindakan kehendak, sementara penggunaan kata kerja marakake tidak menunjukkan tindakan kehendak. Konstruksi kausatif analitik dalam bahasa Jawa dan bahsa Indonesia merupakan konstruksi yang bersifat biklausa. Dalam bahasa Indonesia konstruksi kausatif analitiknya dapat dibentuk 
dengan verba kausatif yang lebih produktif, seperti membuat, meyebabkan, mempersilahkan, menyuruh, meminta dan membikin. Dilihat dari kategori katanya, kausatif analitik bahasa Jawa dan bahasa Indonesia mempunyai dua predikat disetiap konstruksinya, predikat pada konstruksi nonkausatif yang menjadi dasar pembentukan konstruksi kausatif analitik dapat berupa verba intransitif, verba transitif, adjektiva, dan nomina. Pada kausatif analitik dalam bahasa Indonesia komponen sebab maupun akibat, muncul secara eksplisit dalam struktur. Munculnya komponen sebab dan akibat secara eksplisit menyebabkan mudahnya menguraikan situasi-situasi mikro dalam kausatif analitik.

\section{DAFTAR RUJUKAN}

Arka, I Wayan. 1993. Morpholexical Aspects of the -kan Causative in Indonesian. Tesis Master University of Sydney.

Alsina, A. 1992. Onthe Argument Structure of Causative. Linguistic Inquairy, 4: 517555.

Budiarta, I Wayan. 2015. Kontruksi

Kausatif dalam Bahasa

Kemak. Retorika: Jurnal Ilmu Bahasa, Vol. 1, No. 1, pp. 3551.

Goddard, Cliff. 1998. Semantic Analysis - A Practical Introduction. Oxford: Oxford University Press.
Mayani, Luh Anik. 2004. Konstruksi Kausatif dan Aplikatif Bahasa Madura. Tesis Magister Universitas Udayana. E-mail to Winarti, 31 Mei 2008.

2005. Konstruksi

Kausatif Bahasa Madura. Jurnal MLI Th. Ke-23 No. 2, Agustus 2005.

Mulyadi, 2004. Konstruksi Kausatif dalam Bahasa Indoesia. Linguistika.

Shibatani, M. (ed). 1976. Syntax and Semantics. The Grammar of Causative constructions. New York: Academic Press.

Song, Jae Jung. 2001. Linguistic Typology: Morphology and Syntax. London: Long-man.

Sudaryanto. 2015. Metode dan

Aneka Teknik Analisis Bahasa Pengantar Penelitian Wahana Kebudayaan secara Linguistik. Yogyakarta: Sanata Dharma University Press.

Whaley, Lindsay J. 1997. Introduction to Typology: The Unity and Diversity of Language. USA: Sage Publication.

Winarti. 2009. Kontruksi Kausatif Morfologis dan Perifrastis dalam Bahasa Indonesia. Tesis Magister Universitas Indonesia. 7 Januari 2009. 